\title{
Histological and Histochemical Study on the Protective Effect of Curcumin on Ultraviolet Irradiation Induced Testicular Damage in Albino Rats
}

\section{Hafiza A Sharaf', Fatma A Morsy ${ }^{1}$, Nermeen M Shaffie ${ }^{1 *}$ and Ahmed TM El-Shennawy ${ }^{2}$}

${ }^{1}$ Pathology Department, Medical Researches Division, National Research Center, Cairo, Egypt

${ }^{2}$ Histology Department, Faculty of Medicine, Omar Al-Mokhtar University, Lybia

\begin{abstract}
Decrease in the ozone layer leads to increase in the amount of dangerous ultraviolet radiation that reaches the earth's surface. Exposure to ultraviolet radiation leads to tissue damage.

This study aimed to investigate the possible protective effects of curcumin on testicular damage induced by Ultraviolet Irradiation (UVR) histologically, histochemically and morphometrically. 60 albino rats were divide into 5 groups (twelve rats each) the first group served as control. The second group was exposed to ultraviolet $\mathrm{C}$ rays for $1 / 2$ an hour (900 joule) for three consecutive days. The third group was treated with curcumin at a dose level of $5 \mathrm{mg} / \mathrm{kg}$ body weight. The fourth group was treated with curcumin at a dose level of $25 \mathrm{mg} / \mathrm{kg}$ body weight at. The fifth group was treated with curcumin at a dose level of $50 \mathrm{mg} / \mathrm{kg}$ body weight. Rats in the last three groups were treated with curcumin for 4 weeks prior to exposure to ultraviolet rays. Sections were used for histopathological study on image analysis and morphometric measurments. Histochemical stain were used to demonstrate the DNA and glycogen content.

Results of this study revealed that exposure to ultraviolet rays led to changes blood vessels and disturbance of spermatogenic layers, while using curcumin prior to exposure to ultraviolet rays in a small dose $(5 \mathrm{mg} / \mathrm{kg})$ led to restoration of the normal structure in most of the seminiferous tubules. A dose of $25 \mathrm{mg} / \mathrm{kg}$ of curcumin as a protecting agent led to depletion of spermatogenic cells above the level of spermatocytes in many of the tubules, while a dose of $50 \mathrm{mg} / \mathrm{kg}$ of curcumin led to exfoliation of spermatogenic cells in some tubules and depletion of long spermatids.

In conclusion, the present work reported that the treatment of rats with curcumin in a dose of $5 \mathrm{mg} / \mathrm{kg}$ body weight prior to exposure to ultraviolet rays led to a good protection against the harmful effects of ultraviolet $\mathrm{C}$ irradiation, while higher doses of curcumin ( 25 and $50 \mathrm{mg} / \mathrm{kg}$ body weight ) had much less protecting effects.
\end{abstract}

Keywords: Ultraviolet rays; Testis; Rat; Curcumin; Histopathology; Histochemistry; Morphometry

\section{Introduction}

Ultraviolet (UV) light is electromagnetic radiation with wave length shorter than that of the visible light but longer than X-rays [1]. The sun emits ultraviolet light in the UVA, UVB and UVC bands [2]. The Earth's ozone layer blocks $97-99 \%$ of this UV radiation from penetrating through the atmosphere. $98.7 \%$ of the UV radiation that reaches the earth's surface is UVA, some of the UVB and UVC radiation is responsible for the generation of the ozone layer.

The ozone layer shields the earth from the sun's harmful UV rays. Although ozone changes from day to day and place to place, world scientists have measured long term decrease in ozone over the last years. Decrease in ozone layers leads to increase in the amount of dangerous UV radiation that reaches the earth's surface [3]. It caused by release of Chloroflurocarbon (CFCs) and other Ozone Depleting Substances (ODS), which were used widely as refrigerant, including foam and solvent [4].

Solar radiation is the dominant source of ultraviolet exposure and subdivided into several regions based on a combination of physical properties and biological effects. The long wave length range from 320 $400 \mathrm{~nm} /$ energy 3.10-3.94 ev is called UVA [5]. The band from 280-320 $\mathrm{nm} /$ energy 3.94-4.43 ev is called UVB [1], the short wave length range from $180-280 \mathrm{~nm} /$ energy $4.43-12.4 \mathrm{ev}$ is called UVC [6].

$\mathrm{UVC}$ is called a germicidal radiation due to its uses in killing microorganisms. UVB is called the sun burn spectrum of the erythermal band because of its efficiency in causing sunburning of human skin. UVA has been referred to as black light region because of its use to collect of fluorescent minerals, numerous laboratory applications, and sterilization in variety of medical treatment $[7,8]$.

The Ultraviolet Rays (UVR) can cause damage to corneal epithelium and underlying stroma [9], and can cause cataract and other eye damage [10]. Over exposure of people to UVR can lead to skin cancer. The wrinkles, matling, excrescences and flaccidity of aged skin were accepted as inevitable and natural features of ageing. However, it is now thoroughly appreciated that the mere passage of time is insufficient to produce these changes. The ravages associated with ageing are mainly a result of excessive sun exposure [11].

The Ultraviolet Rays (UVR) can be used in the treatment of psoriasis, vitiligo [12,13] and other common skin diseases [14].

${ }^{*}$ Corresponding author: Nermeen M. Shaffie, Pathology Department, National Research Center, Cairo, E-mail: nermshaf@gmail.com

Received September 20, 2012; Accepted November 07, 2012; Published November 09, 2012

Citation: Sharaf HA, Morsy FA, Shaffie NM, El-Shennawy ATM (2012) Histological and Histochemical Study on the Protective Effect of Curcumin on Ultraviolet Irradiation Induced Testicular Damage in Albino Rats. J Cytol Histol 3: 159. doi:10.4172/2157-7099.1000159

Copyright: (c) 2012 Sharaf HA, et al. This is an open-access article distributed under the terms of the Creative Commons Attribution License, which permits unrestricted use, distribution, and reproduction in any medium, provided the original author and source are credited. 
Citation: Sharaf HA, Morsy FA, Shaffie NM, El-Shennawy ATM (2012) Histological and Histochemical Study on the Protective Effect of Curcumin on Ultraviolet Irradiation Induced Testicular Damage in Albino Rats. J Cytol Histol 3: 159. doi:10.4172/2157-7099.1000159

Curcumin (diferuloyl methane) that is an important constituent of rhizomes of the plant Curcuma longa is used as a spice to give specific flavour and yellow color to Curry [15]. Curcumin is the principal curcuminoid of the popular Indian spice turmeric, which is a member of the ginger family (Zingiberaceae). The curcuminoids are natural phenols that are responsible for the yellow color of turmeric [16]. Curcumin exhibits an inhibitory effect on the production of lung injury and pulmonary fibrosis associated with bleomycin instillation in mice [17]. Curcumin inhibited the production of inflammation and acute lung injury in aminal models induced by cyclophosphamide [18], and shown to exhibit a variety of biological activities. In both in vitro and in vivo animal studies,, curcumin has shown antitumor [19], antioxidant, antiarthritic, antiamyloid, anti-ischemic [20], anti-inflammatory properties, which may be due to inhibition of eicosanoid biosynthesis [21] and antiviral activities [22]. Also, it has been shown to inhibit the production of various chemokines and cytokines including Tumour Necrosis Factor a (TNF- $\alpha$ ) by monocytes and alveolar macrophages $[23,24]$.

\section{Material and Methods \\ Ultraviolet radiation- $\mathrm{C}$ source}

Philips ultraviolet lamp $(90 \mathrm{~cm}), 30$ walt and its wavelength $(265$ $275 \mathrm{~nm}$ ). The lamp was hanged in a cover wooden box [ $40 \times 105 \times 90$ $\mathrm{cm}]$. the inner of the box was painted black and divided into 6 equal partitions. The amount of ultraviolet radiation-C received by rats was determined according to the equation of Sybil and Parker [25].

\section{Animals}

A total of 60 male albino rats of Sprague-Dawley rats, weighing about $150 \mathrm{~g}$, were obtained from (National Research Centre, Egypt). The experimental animals were housed in an air conditioned room with $12 \mathrm{~h} / 12 \mathrm{~h}$ light - dark illumination cycles and given distilled water to drink and fed a standard diet ad libitum. They were divided into 5 groups of 12 animals each as follows:

(Group 1) was kept as control group.

(Group 2) were irradiated with UV rays for $1 / 2$ an hour for 3 successive days that is equivelant to a dose of 900 joules/second.

(Group 3) received curcumin orally in a dose of $5 \mathrm{mg} / \mathrm{kg}$ b.w./day for 4 weeks and then radiated with UV radiation in the same dose of group 2 .

(Group 4) received curcumin orally in a dose of $25 \mathrm{mg} / \mathrm{kg}$ b.w./day for 4 weeks and then radiated with UV radiation in the same dose of group 2 .

(Group 5) received curcumin orally in a dose of $50 \mathrm{mg} / \mathrm{kg}$ b.w./day for 4 weeks and then radiated with UV radiation in the same dose of group 2 .

$0-5 \mathrm{mg} / \mathrm{kg}$ bw of curcumin is the acceptance daily intake (ADI), the other doses were chosen according to [26].

\section{Preparation of histological sections}

Testes of dissected animals were removed and fixed in $10 \%$ formol saline, sections of 5-7 $\mu \mathrm{m}$ thickness were stained with haematoxylin and eosin [27] and used for the histopathological and morphometrical studies. For the histochemical investigations, sections were stained with Feulgen technique for DNA [28]. For demonstration of mucopolysaccharides sections were stained with PAS technique [29].
Stained sections were subjected to quantitative analysis using a computerized image analyser. Estimation of the optical density relative to DNA content and nuclear volume were performed using Feulgen stained sections. The diameter of the seminiferous tubules was measured in sections stained with haematoxylin and eosin.

Curcumin was obtained from El hawag factor for raw oils Bader city -Cairo-Egypt, while all chemicals used in staining were obtained from National Research Center, Cairo, Egypt.

\section{Statistical analysis}

The data of histochemical results were subjected to statistical analysis using the student $(\mathrm{t})$ test $(\mathrm{P}<0.05)$ were accepted as significant [30].

This test was used as all groups were compared to control.

\section{Results}

\section{Histological results}

Histological examination of testicular section of control rats showed the normal structure of this tissue (Figure 1a,1b). Exposure of animals to ultraviolet $\mathrm{C}$ rays for $1 / 2$ an hour for 3 successive days that is equivelant to a dose of 900 joules/second caused marked tissue damage in the rat testis in the form of marked dilatation and congestion of blood vessels in interstitial tissue, that appeared wider, lightly stained and contained more vacuolated areas as compared to control (Figure 1c). The arrangement of germ cell rows of spermatogenic cells showed disturbance of spermatogenic layers which appears as areas lacking spermatogenic activity with exfoliation of cells in many of the tubules. Apoptosis of some spermatogenic cells, wide gaps in between them and atrophy of Leydig cells in the interstitial tissue were also occurred (Figure 1c, 1d).

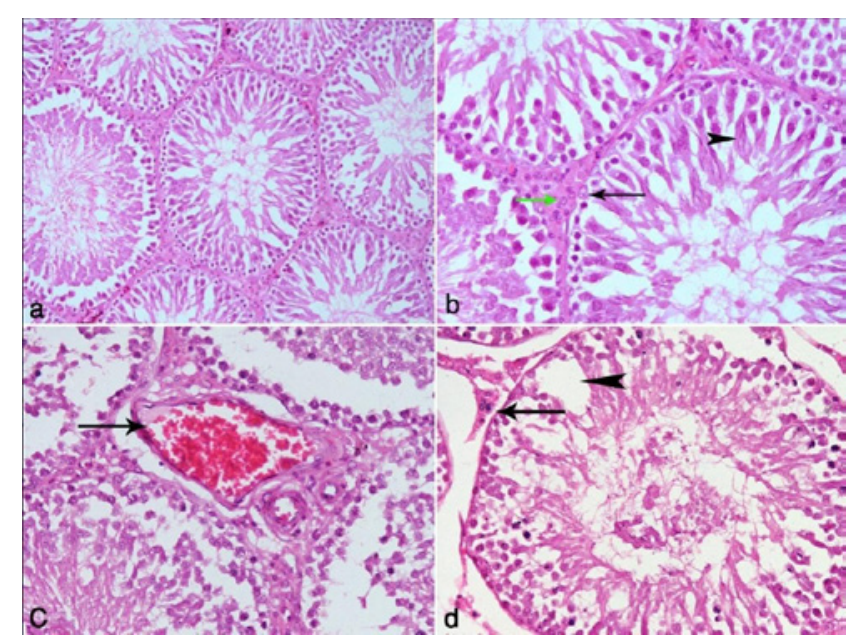

Figure 1: (a) is a photomicrograph of a section of testis from a control rat showing the normal structure of seminiferous tubules. (b) is a higher magnification of the same section showing the different layers of spermatogenic cells with srtoli cells (arrow) and the old (elongated) spermatids (arrow head) attached to it. In the interstitial tissue a number of Leidig cells (green arrow) are observed. (C) is a photomicrograph of a section of testis from a control radiated rat showing marked dilatation and congestion of blood vessels in interstitial tissue (arrow) with disturbance of spermatogenic layers in many of the tubules and exfoliation of cells in others (arrow head). (d) is a photomicrograph of another section of the same group showing wide gaps in between the spermatogenic cells (arrow head). Atrophy of Leidig cells (arrow) in the interstitial tissue is also observed. (Hx. \& E. X 100 \& 200). 
Citation: Sharaf HA, Morsy FA, Shaffie NM, El-Shennawy ATM (2012) Histological and Histochemical Study on the Protective Effect of Curcumin on Ultraviolet Irradiation Induced Testicular Damage in Albino Rats. J Cytol Histol 3: 159. doi:10.4172/2157-7099.1000159

Page 3 of 8

Using curcumin prior to exposure to ultraviolet rays led to improvement in the histological structure of testicular tissue. Using curcumin a dose of $5 \mathrm{mg} / \mathrm{kg}$ b.w./day for 4 weeks prior to irradiation led to restoration of the normal structure in most of the seminiferous tubules except for slight vacuolation in the interstitial tissue and small gaps between the sertoli cells. Spermatocytes showed normal appearance of dividing cells. Sertoli cells, density of spermatids and spermatozoa were more prominent than that of radiated rats (Figure 2a, 2b). Rats received curcumin in a dose of $25 \mathrm{mg} / \mathrm{kg}$ b.w./ day for 4 weeks before irradiation showed multiple gaps in between the spermatogenic cells, depletion of spermatogenic cells above the level of spermatocytes in many of the tubules with no signs of division in these cells, the spermatids are atrophied and the sertoli cells have abnormal-shaped nuclei (Figure 2c, 2d). Using curcumin in a dose of

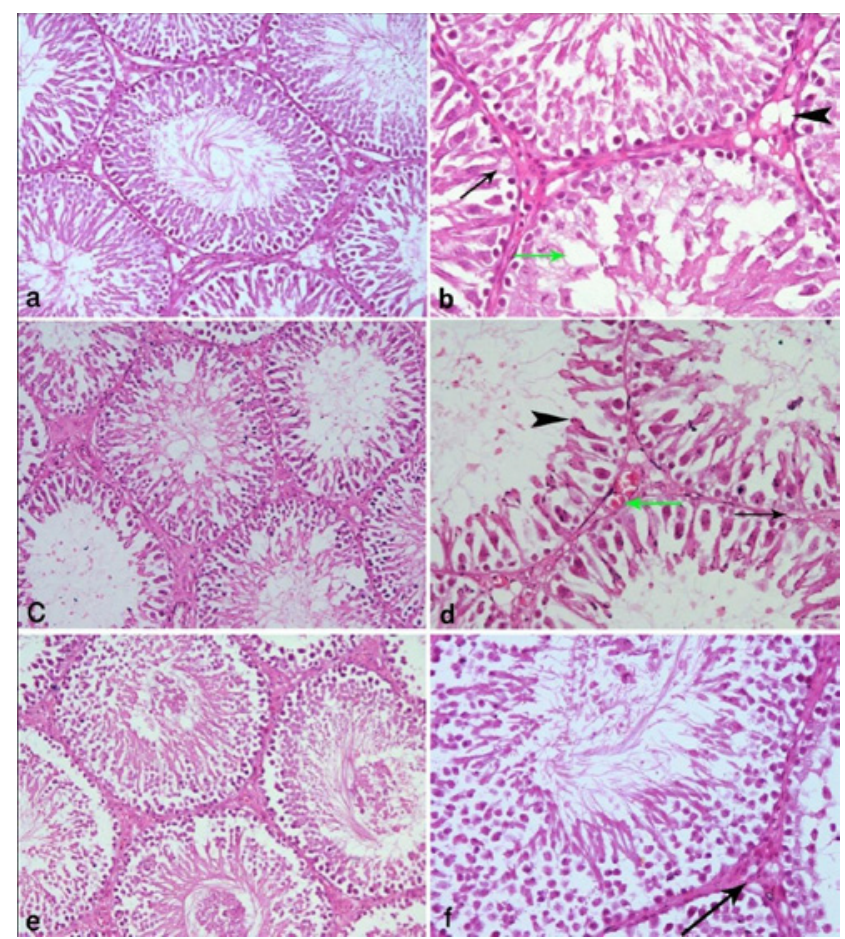

Figure 2: (a) is a photomicrograph of a section of testis from a rat that received curcumin orally in a dose of $5 \mathrm{mg} / \mathrm{kg} \mathrm{b.w./day} \mathrm{for} 4$ weeks and then radiated with UV radiation in the same dose of previous group showing restoration of the normal structure in most of the seminiferous tubules except for slight vacuolation in the interstitial tissue . (b) is a higher magnification of the same section showing some small vacuoles are still present in the interstitial tissue (arrow head) as well as some small gaps inbetween the spermatogenic cells (green arrow). Sertoli cell with old spermatids attached to it is also observed (arrow). (C) is a photomicrograph of a section of testis from a rat that received curcumin orally in a dose of $25 \mathrm{mg} / \mathrm{kg} \mathrm{b.w.l}$ day for 4 weeks and then radiated with UV radiation in the same dose of previous group showing multiple gaps in between the spermatogenic cells (arrow heads) and depletion of spermatogenic cells above the level of spermatocytes in many of the tubules. (d) is a higher magnification of the same section showing no signs of division in spermatocytes, the spermatids are atrophied (arrow head) and the sertoli cells have abnormal-shaped nuclei (arrow). Slight congestion of blood vessels is observed in interstitial tissue (green arrow). (e) is a photomicrograph of a section of testis from a rat that received curcumin orally in a dose of $50 \mathrm{mg} / \mathrm{kg} \mathrm{b.w./day} \mathrm{for} 4$ weeks and then radiated with UV radiation in the same dose of previous group showing thickening of the basement membrane of seminiferous tubules (arrow heads), exfoliation of spermatogenic cells (arrow) in some tubules and disturbance of spermatobegic layers in others. (f) is a higher magnification of the same section showing depletion of long spermatids and the presence of gaps between the spermatogenic cells (arrow). (Hx. \& E. X 100 \& 200).

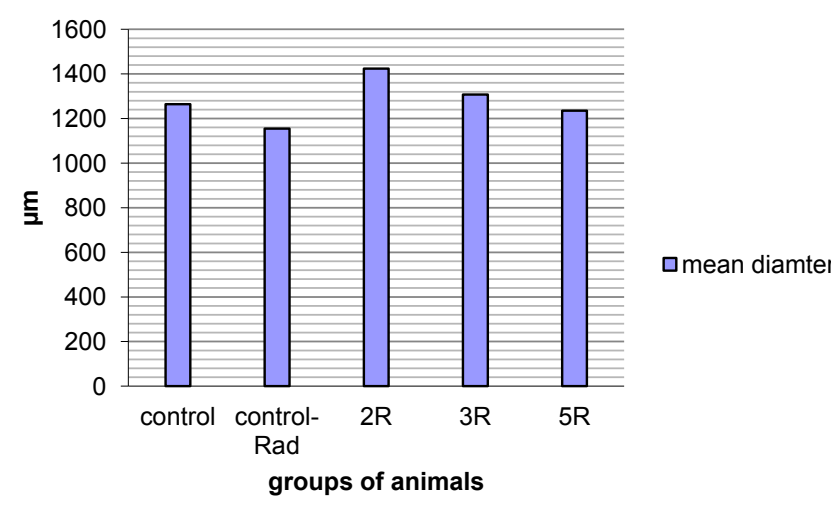

Histogram 1: The diameter of seminiferous tubules in all groups.

\begin{tabular}{|c|c|c|c|c|c|}
\hline group & Cont. & Cont. R & $\mathbf{5}$ mg cur & $\mathbf{2 5}$ mg cur & $\mathbf{5 0}$ mg cur \\
\hline $\begin{array}{c}\text { Mean } \\
\text { diameter }\end{array}$ & 1264,545 & 1154,649 & 1423,835 & 1307,319 & 1235,02 \\
\hline
\end{tabular}

Table 1: The mean diameter of seminiferous tubules of all groups.

$50 \mathrm{mg} / \mathrm{kg}$ b.w./day for 4 weeks prior to iradiation led to thickening of the basement membrane of seminiferous tubules, exfoliation of spermatogenic cells in some tubules and disturbance of spermatogenic layers in others, depletion of long spermatids and the presence of gaps between the spermatogenic cells (Figure 2e, 2f).

\section{Morphometrical results}

Examination of the mean diameter of seminiferous tubules revealed that ultraviolet $\mathrm{C}$ irradiation caused a noticeable decrease in diameter of seminiferous tubules if compared to control rats. Treating animals with curcumin as a protecting agent against the harmful effects of ultraviolet $\mathrm{C}$ radiation showed an increase in diameter of seminiferous tubules more than control and radiated animals with doses of 5, 25 and $50 \mathrm{mg} / \mathrm{kg}$ respectively (Histogram 1 and Table 1).

Examination of sections of control rats to identify the percentage of different stages of seminiferous tubules in the rat tesiticular tissue revealed that 14 stages were found in the seminiferous tubules of the rat as follows: stage 1: $6.2 \%$, stage $2: 9.9 \%$, stage $3: 7.7 \%$, stage $4: 9.6 \%$, stage $5: 7.2 \%$, stage $6: 8.9 \%$, stage $7: 6.8 \%$, stage $8: 9.1 \%$, stage $9: 6.1 \%$, stage $10: 4.6 \%$, stage $11: 3.9 \%$, stage $12: 6.8 \%$, stage $13: 7.5 \%$ and stage 14: $4 \%$ and $1.7 \%$ showed exfoliated cells 9 (Figure 2,3).

Examination of sections of radiated rats revealed that: stage 1 : $3.3 \%$, stage $2: 4.2 \%$, stage $3: 1.6 \%$, stage $4: 2.7 \%$, stage $5: 1.3 \%$, stage 6 ; $13.6 \%$, stage $7: 6.6 \%$, stage $8: 6.2 \%$, stage $9: 6 \%$, stage $10: 3.1 \%$, stage 11 : $3 \%$, stage $12: 6.4 \%$, stage $13: 7 \%$ and stage $14: 3.1 \%$ and $31.9 \%$ showed exfoliated cells.

Examination of sections of rats received $5 \mathrm{mg} / \mathrm{kg}$ curcumin prior to radiation revealed values close to those of control rats. Animals received curcumin in a dose of $25 \mathrm{mg} / \mathrm{kg}$ body weight before radiation showed arrest of spermatogenesis in most of the tubules above the level of the spermatocytes, while animals received curcumin in a dose of 50 $\mathrm{mg} / \mathrm{kg}$ body weight before radiation showed nearly close to those of radiated group.

\section{Histochemical results}

DNA was histochemically demonstrated using Feulgen reaction 
technique. The mean value per nucleus was measured by image analyzer and the results was expressed as optical density values. The mean value for nuclear DNA content of spermatogonia (Sg) nuclei was non-significantly lower in radiated group $(156,660)$ than control $(165,506)$. The mean value for nuclear DNA content of spermatocytes (Sc) nuclei was significantly lower in irradiated group $(165,506)$ than control $(237,241)$.

The mean DNA content of spermatogonia in curcumin treated groups were non-significantly lower than that of control group, on the other hand, the mean DNA content of spermatocytes in curcumin treated groups with were significantly lower than that of control animals, (Histogram 2).

By measuring the optical density of mucopolysaccharide content in testicular tissue of sections stained with PAS (Histogram 3 and Table 2) revealed that UVC irradiation caused marked diminution of mucopolysaccharides content in testicular tissue of rat $(72,432 \pm$ $37,532)$ if compared to that of control rats $(111,671 \pm 21,797)$ (Figure $4 \mathrm{a}, 4 \mathrm{~b})$. Using curcumin as a protective agent against the damaging effect of UV irradiation in a dose of $5 \mathrm{mg} / \mathrm{kg}$ body weight showed diminution of the mucopolysaccharide content in testicular tissue $(46,748 \pm 8,624)$ if compared with normal control group (Figure 4C). Curcumin in higher doses ( $25 \mathrm{mg} / \mathrm{kg}$ body weight) had slight protective effect against the damaging effect of UV irradiation $(69,409 \pm 25,28009)$ as mucopolysaccharide content was still less than that of control group (Figure $4 \mathrm{~d}$ ). The highest dose of curcumin had a similar effect to that of the lowest dose $(5 \mathrm{mg} / \mathrm{kg})$ body weight $(47,314 \pm 27,46729)$ (Figure $4 \mathrm{e})$.

\section{Discussion}

All living organisms on Earth are being perpetually exposed to some amount of radiation originating from a variety of sources. Ionizing radiation are serving on mankind many fold than any other scientific invention in the form of medical, industrial, agricultural applications

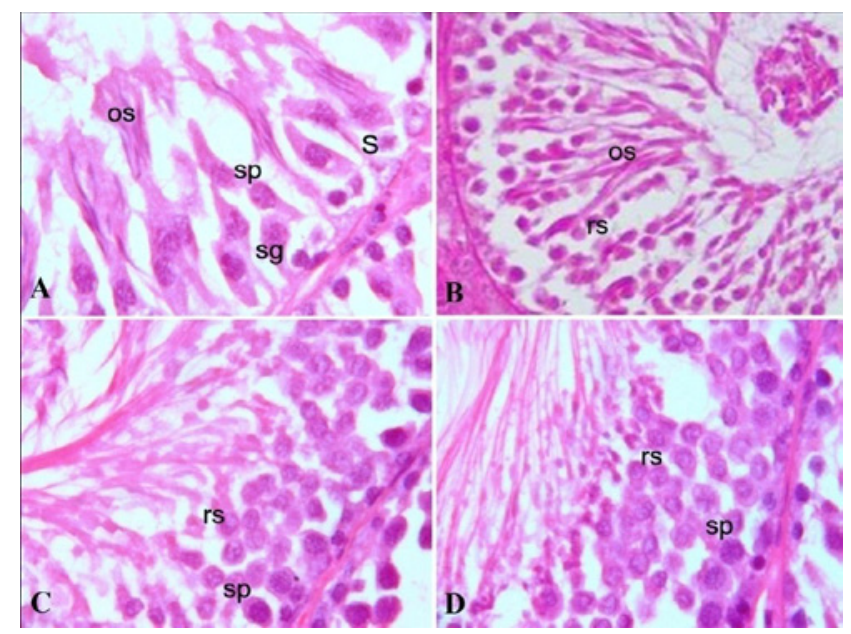

Figure 3: (A) A section of a seminiferous tubule showing stage 4 showing old (elongated) spermatids (os) near the lumen of the tubule, 2 generations of spermatocytes (sp), dark nucleus of spermatogonia ( $\mathrm{sg}$ ) and triangular nucleus of sertoli cell (S). (B) stage 6 of seminiferous tubule showing old spermatids (0s) inserted in sertoli cell cytoplasm and many rows of rond spermatids ( $r s$ ). (C) stage 7 of seminiferous tubules showing multiple rows of round spermatids ( $r s$ ) and a single row of spermatocytes (sp). (D) stage 8 showing round spermatids (rs) and spermatocytes (sp). (Hx. \& E. X 500, 1000).

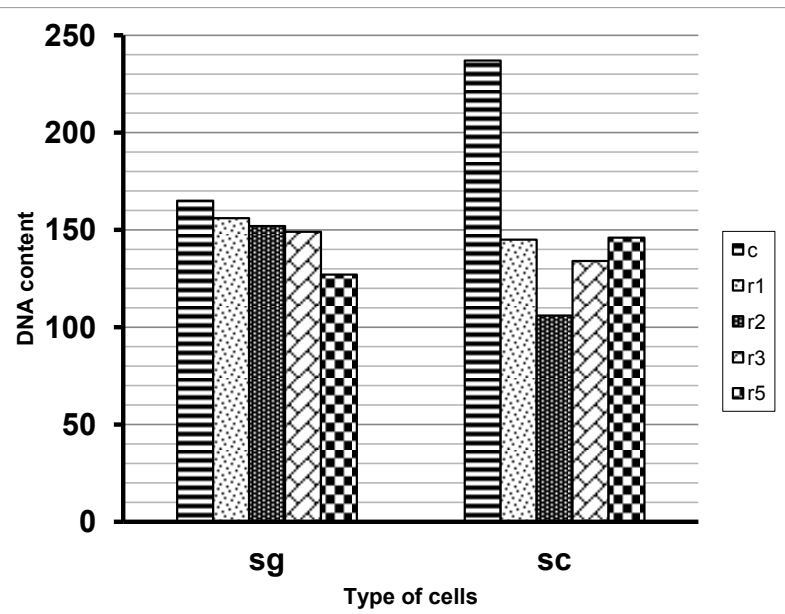

Histogram 2: The DNA content of spermatogonia $(\mathrm{Sg})$ and spermatocytes (Sc) of all groups.

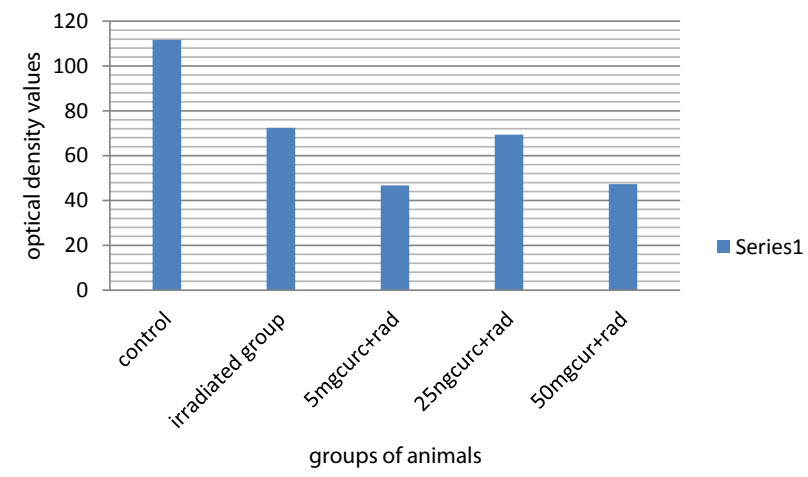

Histogram 3: The mucopolysaccharide content in testicular tissue of all groups.

\begin{tabular}{|c|c|c|c|c|}
\hline Control & Cont. radiated & 5mg cur + rad & $\begin{array}{c}\text { 25mg cur + } \\
\text { rad }\end{array}$ & $\begin{array}{c}\text { 50mg cur + } \\
\text { rad }\end{array}$ \\
\hline 111,67147 & 72,43230088 & 46,74865868 & 69,40910673 & 47,3145994 \\
\hline 21,79721 & 37,53281 & 8,624313 & 25,28009 & 27,46729 \\
\hline
\end{tabular}

Table 2: The mucopolysaccharide content in testicular tissue of all groups.

and scientific solutions. Whole body exposure to irradiation causes damage initiating plethora of cellular and biochemical reactions inside living cells. Various tissue and organ systems of an individual differ in their response to radiation and as a rule, systems with proliferating cells are the most sensitive. Testis is one of the radiosensitive organs due to rapidly dividing cell renewal system. Radiation was found to produce marked effects on testis in term of lethality and impaired spermatogenesis [31].

In the present work identical apoptosis was detected in the group of animals exposed to ultraviolet $C$ rays only. These results were in agreement with $[32,33]$ they noticed that total body irradiation induces an increase of identical apoptosis and testicular damage, they are also coinciding with Veselska and Janisch [34], who demonstrated that short reparation periods from 30 minutes to 3 hours (ultraviolet rays) caused an increase in number of apoptotic cells with typical features (plasma membrane blebbing and DNA fragmentation). The surviving cells were 
Citation: Sharaf HA, Morsy FA, Shaffie NM, El-Shennawy ATM (2012) Histological and Histochemical Study on the Protective Effect of Curcumin on Ultraviolet Irradiation Induced Testicular Damage in Albino Rats. J Cytol Histol 3: 159. doi:10.4172/2157-7099.1000159

characterized by other changes in morphology i.e. shrinking of normal cells and a gear wheel shape of giant multinuclear cells. Production and accumulation of apoptotic cells is one of characteristic features of tissue damage by oxidative stress [35]. Increase apoptotic cells induced by ultraviolet rays has been explained by Veselska and Janisch and Su Liu et al. $[34,36]$ they postulated that exposure of organisms to ultraviolet rays induced effects on cell structure and function. Ultraviolet rays cause damage to cell structure by oxidative stress. At molecular level, chromophores without DNA absorb photon; this absorption results in production of reactive oxygen species and energy transfer to target molecules, i.e.DNA, protein and lipids. The reaction of oxygen species plays an important role in causing DNA lesions as well as changes in metabolism related to cell damage and induction of apoptosis.

In the present study devoid of germ cells in some tubules, decrease in density of sperms and gaps in spermatogenic layers in others were observed after exposure to ultraviolet rays. These results were in agreement with [37] they observed that after irradiation most of the tubules of testis appeared devoid of germ cells and contained only a single row of cells attached to tubular basal lamina, others showed decrease in sperm density and viability. Also, Kim and Lee [38] stated that radiation induced extant of changes in mouse testis structure and

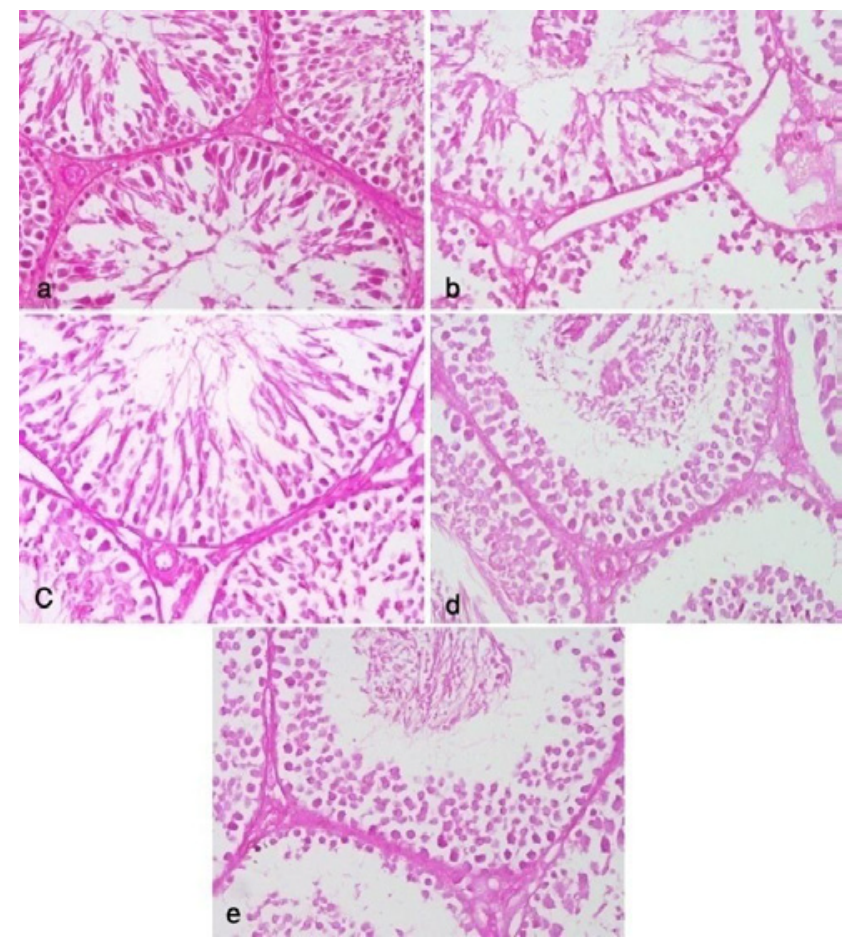

Figure 4: (a) is a photomicrograph of a section of testis from a control rat showing the normal content of mucopolysaccharides in testicular tissue. (b) is a photomicrograph of a section of testis from a control radiated rat showing amarked decrease in mucopolysaccharide content compared with previous group. (C) is a photomicrograph of a section of testis from a rat that received curcumin orally in a dose of $5 \mathrm{mg} / \mathrm{kg} \mathrm{b.w./day} \mathrm{and} \mathrm{then}$ radiated with UV radiation in the same dose of previous group showing diminution of the mucopolysaccharide content of testicular tissue. (d) ) is a photomicrograph of a section of testis from a rat that received curcumin orally in a dose of $25 \mathrm{mg} / \mathrm{kg} \mathrm{b.w./day} \mathrm{and} \mathrm{then} \mathrm{radiated} \mathrm{with} \mathrm{UV} \mathrm{radiation} \mathrm{showing}$ that mucopolysaccharide content of tissue is much less than that of control group. (e) is a photomicrograph of a section of testis from a rat that received curcumin orally in a dose of $50 \mathrm{mg} / \mathrm{kg} \mathrm{b.w./day} \mathrm{and} \mathrm{then} \mathrm{radiated} \mathrm{with} \mathrm{UV}$ radiation showing a remarkable diminution of mucopolysaccharide content if compared with the control group. (PAS X 200). epididymal sperm parameters following radiation. The histological examination of seminiferous tubules showed reversible spermatogenic cell loss. According to Gehlot et al. [39] ionizing radiation was found to produce marked effects on testis in term of lethality and impairment spermatogenesis. In previous reports it was documented that the ultraviolet light induced tubular disorganization and degenerative effect of spermatogenesis in bovine, mouse and rats [40]. These results are explained by Lanning et al. [41] who stated that such findings can be due to disturbance of Sertoli cell function leading to vacuolation of organelles or vacuolation disturbance of fluid balance.

Exfoliation of germ cells was observed in the results of this study and can be explained according to Lanning et al. [41] who postulated that it may be due to disruption of Sertoli/germ cell junctions leading to loss of adhesion or it may be due to disruption of Sertoli cell cytoskeletal fibers leading to sloughing of apical Sertoli cell cytoplasm and attached germ cells.

In the present study the decrease in diameter of seminiferous tubules and shrinkage of some seminiferous tubules were detected in the group of rats exposed to ultraviolet rays only. Results of this work were in agreement with Goyal and Gehlot [39] they noticed that decrease in diameter and lumen of seminiferous tubules were propably resulted from spermatogenic cell loss after radiation exposure. Also Kim and Lee [38] reported that spermatogenic cell lines were separated from one another and their cytoplasm was filled with diffuse vacuoles with wrinkling in the basement membrane of the seminiferous tubules.

In cells the interaction between a number of environmental and occupational genotoxic substances such as X-rays, ultraviolet rays and a variety of chemicals including ozone results in an enhanced generation of free radicals and modified prooxidant states. The ultraviolet light exposed cells can induce the production of reactive oxygen species which can damage the cellular elements [42]. Oxidative stress plays a causative role in the development of degeneration effect of radiation on seminiferous tubules consistent with results observed in the present work. This is coinciding with Heemen et al. [43], who found that exposure of rats to ultraviolet A (320-400nm) induced histological damage in tissues.

The pathological changes observed in the present work in the testis of rats due to ultraviolet $\mathrm{C}$ rays may be atributed to lipid peroxidation and free radicals in damaged cells. Our results are in agreement with Santra and Manna [44] as they found lipid accumulation in mammals within testicular tissues, especially in the sertoli cells due to local irradiation or after high dose of ionization radiation.

The role of reactive oxygen species in radiation injury and the potential of antioxidants to reduce these deleterious effects have been studied in animal models for more than 50 years. Sharma et al. [45] reported that many natural antioxidants have antimutagenic properties and proved to be effective radioprotectors. Modulation of endogenous antioxidants such as superoxide dismutase may be useful in specific radiotherapy protocols.

Curcumin have been shown to scavange the free radicals and thereby acts as good antioxidant. Its role as an antioxidant may be due to in part its ability to down regulate nitric oxide formation, which is a key element in inflammation and may contribute to carcinogenesis [46].

The antioxidant activity of the curcuminoids (the active part in curcumin) comes by virtue of their chemical structure. The 
curcuminoids consist of two methoxylated phenols connected by two a, B unsaturated carbonyl groups that exist in a stable phenol form [47].

In the present work the oral administration of curcumin prior to irradiation with ultraviolet $\mathrm{C}$ rays showed some improvement in pathological changes in the form of absence of apoptotic cells and normalization of spermatogenic layer. These results were in agreement with [48] who noticed that Curcuma longe has antioxidant properties and can prevent UV-induced apoptotic changes and abolish oxidative stress. These results can be explained by Asuda et al. [47] who stated that Curcumin has been shown to inhibit lipid peroxidation using linoleate, a polyunsaturated fatty acid that is able to be oxidized and form a fatty acid radical. It has been demonstrated that curcumin acts as a chainbreaking antioxidant at the 3 ' position, resulting in an intramolecular Diels-Alder reaction and neutralization of the lipid radicals.

In addition to inhibiting lipid peroxidation, curcumin demonstrates free radical-scavenging activity. It has been shown to scavenge various reactive oxygen species produced by macrophages (including superoxide anions, hydrogen peroxide and nitrite radicals) both in vitro as well as in vivo [49].

Moreover, curcumin a polyphenolic antioxidant has the ability of supression of expression of the isoenzyme cyclooxegenosis. Its efficacy appears to be related to induction of glutathione s-transferase enzyme, which is responsible of inhibition of injuries induced in tissue. It also inhibits the prostaglandin E(PGE2) production [45].

Curcumin has been shown to suppress the activation of NF- $\mathrm{KB}$, an inducible transcription factor that regulates the expression of a host of genes involved in inflammation, cellular proliferation and cell survival [50].

Concerning the histochemical results in the present work, rats exposed to ultraviolet rays showed a significant decrease in DNA especially in spermatocytes. Results of this work were in agreement with Fourtanier and Berrebi [51] who noticed that UVA and UVC radiation induced DNA damage and this damage is not a result of lipid peroxidation. UVC radiation is known to induce a transient cellular replicative arrest or apoptosis.

According to Taggart [52] ultraviolet radiation mostly damage DNA by producing thymin dimers, which are cross-links between adjacent pyrimidine bases in DNA strand. Short wave length UV light has enough energy to damage chemical bonds between DNA molecules, which are very stable under most conditions. Also, Onigbinde et al. [53] reported that ultraviolet photons harm the DNA molecules of the living organisms in different ways. In one common damage event, adjacent thymine bases bond to each other instead of across the "ladder". This make a bluge and the distorted DNA molecules do not function properly. Damaged DNA was found to be elevated upon a single ultraviolet exposure and return to background level after 3-4 days.

In the present work, the treatment of rats with curcumin prior to ultraviolet radiation showed a non-significant decrease in DNA in spermatogonia cells, while spermatocytes-actively dividing cellsshowed a significant decrease in DNA in comparison to control especially with the small dose of curcumin. Results of the present work were agreed to Notarbartolo et al. [54] who stated that Curcumin was shown to inhibit cell growth and had apoptotic effects that is somewhat related to free radical generation and is dependent on caspase 9 and 3 activation. While Chan and $\mathrm{Yu}$ [48] stated that curcumin exerted a good ability to scavange oxygen free radicals and could protect DNA from UV-induced damage. Also, Sharma et al. [45] reported that curcumin can play a significant role in suppression of oxidative DNA adduct formation.

Curcumin induces apoptotic cell death by DNA-damage and preventing cancerous cell growth [55].

The rats exposed to ultraviolet rays showed diminution in PAS +ve materials in testis. These results go in agreement with Morsy et al. [56] who found that the liver of rats exposed to ultraviolet $C$ rays (180 $-280 \mathrm{~nm}$ ) for 30 successive days showed marked diminution in PAS +ve materials in the cytoplasm of hepatocytes. They are also coinciding with Farrag [57], who found that the rats exposed to ultraviolet light (5 joules) daily for 10 days showed decrease in PAS reaction in brush borders of renal tubules. Treating rats with curcumin in a dose of 5 $\mathrm{mg} / \mathrm{kg}$ prior to irradiation led to diminution of PAS + ve materials in testicular tissue, which can be explained by occurence of regeneration in the form of increased number of spermatocytes and round spermatids, while the number of elongated spermatids (containing acrosomes) is still low. Curcumin in a dose of $25 \mathrm{mg} / \mathrm{kg}$ gave a higher +ve result that can be explained by thickening of basement membrane of seminiferous tubules. Using curcumin in a dose of $50 \mathrm{mg}$ gave similar result to that of dose $5 \mathrm{mg} / \mathrm{kg}$. El-Bamhawy et al. [58] reported that in general, the reduction of glycogen content could be due to the release of hydrolytic enzymes from ruptured lysosomes under the toxic effects of toxic agents. Also, El-Asar et al. [59] reported that irradiation caused distention and fragmentation of elements of endoplasmic reticulum with absence of ribosomes and glycogen particles.

The decrease in PAS +ve material observed in this study was interpreted due to the most probably consequent to the degenerative changes [60].

Contrary to the antioxidant nature of curcuminoids, much evidence for cytotoxic properties of curcumin was reported, and its cytotoxicity is suggested to be due to production of reactive oxygen species and causes oxidative DNA damage [61].

Curcumin, like ascorbic acid, can become a pro-oxidant agent depending on the redox state of the biological environment [62]. Therefore, the mutagenic effects of curcumin could be explained by the fact that curcumin would act as a pro-oxidant agent at the highest concentrations [62].

In conclusion, the present work reported that the treatment of rats with curcumin in a dose of $5 \mathrm{mg} / \mathrm{kg}$ body weight prior to exposure to ultraviolet rays led to a good protection against the harmful effects of ultraviolet $\mathrm{C}$ irradiation, while higher doses of curcumin (25 and 50 $\mathrm{mg} / \mathrm{kg}$ body weight ) had much less protecting effects.

\section{References}

1. Kelly DA, Seed PT, Young AR, Walker SL (2003) A commercial sunscreen's protection against ultraviolet radiation-induced immunosuppression is more than $50 \%$ lower than protection against sunburn in humans. J Invest Dermatol 120: $65-71$.

2. Hanson KM, Gratton E, Bardeen CJ (2006) Sunscreen enhancement of UV induced reactive oxygen species in the skin. Free Radic Biol Med 41: 12051212.

3. Thiele JJ, Dreher F, Maibach HI, Packer L (2003) Impact of ultraviolet radiation and ozone on the transepidermal water loss as a function of skin temperature in hairless mice. Skin Pharmacol Appl Skin Physiol 16: 283-290.

4. Lucas RM, Ponsonby AL (2002) Ultraviolet radiation and health: friend and foe. Med J Aust 177: 594-598. 
Citation: Sharaf HA, Morsy FA, Shaffie NM, El-Shennawy ATM (2012) Histological and Histochemical Study on the Protective Effect of Curcumin on Ultraviolet Irradiation Induced Testicular Damage in Albino Rats. J Cytol Histol 3: 159. doi:10.4172/2157-7099.1000159

Page 7 of 8

5. El-Makawy A, Sharaf HA (2006) Cytogenetical and histochemical studies on curcumin in male rats. Environmental toxicology 10: 169-180.

6. Bode AM, Dong Z (2003) Mitogen-activated protein kinase activation in UVinduced signal transduction. Sci STKE 2003: RE2.

7. Mittal A, Elmets CA, Katiyar SK (2003) CD11b+ cells are the major source of oxidative stress in UV radiation-irradiated skin: possible role in photoaging and photocarcinogenesis. Photochem Photobiol 77: 259-264.

8. Sinha RP and Hader DP (2002) UV induced DNA damage and repair: A review. Photochem. Photobiol Sci 1: 225-236.

9. Zikri M (2006) Histological and immunohistochemical study on the protective effect of vidisept eye drops on ultraviolet irradiated cornea of albino rats. The Egyptien Journal of Histology 29: 9-20

10. Hiramoto K, Yanagihara N, Sato EF, Inoue M (2003) Ultraviolet B irradiation of the eye activates a nitric oxide-dependent hypothalamopituitary proopiomelanocortin pathway and modulates functions of alpha-melanocytestimulating hormone-responsive cells. J Invest Dermatol 120: 123-127.

11. Mahon SM (2003) Skin cancer prevention: education and public health issues. Semin Oncol Nurs 19: 52-61.

12. Tahir R, Mujtaba G (2004) Comparative efficacy of psoralen - UVA photochemotherapy versus narrow band UVB phototherapy in the treatment of psoriasis. J Coll Physicians Surg Pak 14: 593-595.

13. Atwa MA, Mohamed A and Khalil M (2006) Narrow band UVB decrease epidermal thickness, mast cell densityand downregulates IL-8 expresionin psoriatic lesions. The Egyptien Journal of Histology 29: 115-124.

14. Smith G, Dawe RS, Clark C, Evans AT, Comrie MM, et al. (2003) Quantitative real-time reverse transcription-polymerase chain reaction analysis of drug metabolizing and cytoprotective genes in psoriasis and regulation by ultraviole radiation. J Invest Dermatol 121: 390-398.

15. Kumar A, Dhawan S, Hardegen NJ, Aggarwal BB (1998) Curcumin (Diferuloylmethane) inhibition of tumor necrosis factor (TNF)-mediated adhesion of monocytes to endothelial cells by suppression of cell surface expression of adhesion molecules and of nuclear factor-kappaB activation. Biochem Pharmacol 55: 775-783.

16. Kolev, Tsonko M, Velcheva, Evelina A, Stamboliyska, et al. (2005) DFT and experimental studies of the structure and vibrational spectra of curcumin. International Journal of Quantum Chemistry 102 (6): 1069-79.

17. Ahmed AM (2005) Inhibition of bleomycin induced lung damage in mice by curcumin. The Egyptien Journal of Histology, 28(2): 211-220.

18. Venkatesan N, Chandrakasan G (1995) Modulation of cyclophosphamideinduced early lung injury by curcumin, an anti-inflammatory antioxidant. Mol Cell Biochem 142: 79-87.

19. Ströfer M, Jelkmann W, Depping R (2011) Curcumin decreases survival of Hep3B liver and MCF-7 breast cancer cells: the role of HIF. Strahlenther Onkol 187: 393-400.

20. Shukla PK, Khanna VK, Ali MM, Khan MY, Srimal RC (2008) Anti-ischemic effect of curcumin in rat brain. Neurochem Res 33: 1036-1043.

21. Stix G (2007) Spice Healer. Sci Am 296: 54-57.

22. Mazumder A, Raghavan K, Weinstein J, Kohn KW, Pommier Y (1995) Inhibition of human immunodeficiency virus type-1 integrase by curcumin. Biochem Pharmacol 49: 1165-1170.

23. Chan MM (1995) Inhibition of tumor necrosis factor by curcumin, a phytochemical. Biochem Pharmacol 49: 1551-1556.

24. Abe Y, Hashimoto S, Horie T (1999) Curcumin inhibition of inflammatory cytokine production by human peripheral blood monocytes and alveolar macrophages. Pharmacol Res 39: 41-47.

25. Harris FS (1984) McGraw-Hill Concise Encyclopedia of Science and Technology. Edited by Sybil P. Parker. Appl Opt 23: 2291.

26. Choudhary D, Chandra D, Kale RK (1999) Modulation of radioresponse of glyoxalase system by curcumin. J Ethnopharmacol 64: 1-7.

27. Drury RVA and Walligton EA (1980) Carltons Histological techniques, 5th ed Oxford University Press, New York, Pronto, 206.

28. Feulgen R and Rosenbeck HC (1942) Manual of Histological Demonstration Technique. Butter worth \& Co (publishers) Ltd. London, Therford, havrhill.
29. McMANUS JF, CASON JE (1950) Carbohydrate histochemistry studied by acetylation techniques. J Exp Med 91: 651-654.

30. Norusis MJ (1988) The SPSS guide to data analysis for SPSS/PC.SPSS.Inc

31. Sharma P, Parmar J, Sharma P, Verma P, Goyal PK (2011) Radiation-Induced Testicular Injury and Its Amelioration by Tinospora cordifolia (An Indian Medicinal Plant) Extract. Evid Based Complement Alternat Med 2011: 643847.

32. Hussein A M, Abu-Deif EE, Abou El-Ghait AT, Adly MA and Abdelreheem MH (2008) Morphological evaluation on the radioprotective effects of melatonin against $X$-rays induced early and acute testis damage in albino rats: an animal model. Int J Exp Pathol 87: 237-250.

33. Cordelli E, Fresegna AM, Leter G, Eleuteri P, Spanò M, et al. (2003) Evaluation of DNA damage in different stages of mouse spermatogenesis after testicular $X$ irradiation. Radiat Res 160: 443-451.

34. Veselska R and Janisch R (2000) The effect of UV irradiation on changes in cytoskeleton and viability of mouse fibroblasts L929 cell line. Scripta Medica 73: $393-408$.

35. Kagan VE, Kisin ER, Kawai K, Serinkan BF, Osipov AN, et al. (2002) Toward mechanism-based antioxidant interventions: lessons from natural antioxidants. Ann N Y Acad Sci 959: 188-198.

36. Su Liu, Shian-Jang Yan, Yi-Fen Lee, Ning-Chun Liu, Huei-Ju Ting, et al. (2011) Testicular Nuclear Receptor 4 (TR4) Regulates UV Lightinduced Responses via Cockayne Syndrome B Proteinmediated Transcription-coupled DNA Repair. The Journal of Biological Chemistry. Vol. 286: 38103-3810.

37. van Pelt AM, Roepers-Gajadien HL, Gademan IS, Creemers LB, de Rooij DG, et al. (2002) Establishment of cell lines with rat spermatogonial stem cell characteristics. Endocrinology 143: 1845-1850.

38. Kim JK, Lee CJ (2000) Effect of exogenous melatonin on the ovarian follicles in gamma-irradiated mouse. Mutat Res 449: 33-39.

39. Goyal PK, Gehlot P (2009) Radioprotective effects of Aloe vera leaf extract on Swiss albino mice against whole-body gamma irradiation. J Environ Pathol Toxicol Oncol 28: 53-61.

40. Izadyar F, Matthijs-Rijsenbilt JJ, den Ouden K, Creemers LB, Woelders H, et al (2002) Development of a cryopreservation protocol for type A spermatogonia. J Androl 23: 537-545.

41. Lanning LL, Creasy DM, Chapin RE, Mann PC, Barlow NJ, et al. (2002) Recommended Approaches for the Evaluation of Testicular and Epididyma Toxicity. Toxicologic Pathology, 30: 507-520.

42. Abarca JF, Casiccia CC (2002) Skin cancer and ultraviolet-B radiation under the Antarctic ozone hole: southern Chile, 1987-2000. Photodermato Photoimmunol Photomed 18: 294-302.

43. Heenen M, Giacomoni PU, Golstein P (2001) Individual variations in the correlation between erythemal threshold, UV-induced DNA damage and sunburn cell formation. J Photochem Photobiol B 63: 84-87.

44. Santra KB and Manna CK (2009) X-rays induced changes in biochemical and histochemical parameters in the testis of male wild Indian House rat, Rattus rattus Cey J SG 38: 39-49.

45. Sharma RA, Euden SA, Platton SL, Cooke DN, Shafayat A, et al. (2004) Phase I clinical trial of oral curcumin: biomarkers of systemic activity and compliance. Clin Cancer Res 10: 6847-6854.

46. Motterlini R, Foresti R, Bassi R, Green CJ (2000) Curcumin, an antioxidant and anti-inflammatory agent, induces heme oxygenase- 1 and protects endothelial cells against oxidative stress. Free Radic Biol Med 28: 1303-1312.

47. Masuda T, Maekawa T, Hidaka K, Bando H, Takeda Y, et al. (2001) Chemical studies on antioxidant mechanism of curcumin: analysis of oxidative coupling products from curcumin and linoleate. J Agric Food Chem 49: 2539-2547.

48. Chan WH and Yu JS (2006) Curcumin inhibit UV irradiation induced oxidative stress and apoptotic biochemical changes in human epidermoid carcinoma AA31 cells. Journal of cellular biochemistry 90: 327-338.

49. Joe B, Vijaykumar M, Lokesh BR (2004) Biological properties of curcumincellular and molecular mechanisms of action. Crit Rev Food Sci Nutr 44: 97 111

50. Panicker SR, Kartha CC (2010) Curcumin attenuates glucose-induced monocyte chemoattractant protein-1 synthesis in aortic endothelial cells by modulating the nuclear factor-kappaB pathway. Pharmacology 85: 18-26. 
Citation: Sharaf HA, Morsy FA, Shaffie NM, El-Shennawy ATM (2012) Histological and Histochemical Study on the Protective Effect of Curcumin on Ultraviolet Irradiation Induced Testicular Damage in Albino Rats. J Cytol Histol 3: 159. doi:10.4172/2157-7099.1000159

Page 8 of 8

51. Fourtanier A, Berrebi C (1989) Miniature pig as an animal model to study photoaging. Photochem Photobiol 50: 771-784

52. Taggart R and Starr C (2006) The Unity and Diversity of Life: Mutated Genes and Their Protein Products. 14: 227.

53. Onigbinde AT, Adedoyin RA, Ojoawo OA, Johnson OE, Obembe AO, et al. (2010) Effects of ultraviolet radiation (type B) on wound exudates, appearance and depth description. Technol Health Care 18: 297-302.

54. Notarbartolo M, Poma P, Perri D, Dusonchet L, Cervello M et al. (2005) Antitumor effect epossibeurcumin alone or in combination with cispplatin or doxorucibin on human hepatic cancer cells. Analysis of their relationship to change in NF-KB activation level and in IAP gene expression. Cancer Lett 16: $53-65$.

55. Martín-Cordero C, López-Lázaro M, Gálvez M, Ayuso MJ (2003) Curcumin as a DNA topoisomerase II poison. J Enzyme Inhib Med Chem 18: 505-509.

56. Morsy FA, Abbas NF and Sharaf HA (2004) Hepatoprotective effect of garlic (Allium Sativum) and vitamin $\mathrm{E}$ on experimental liver injuries induced by ultraviolet radiation. J Egypt Soc Toxicol 30: 9-22.
57. Farrag ARH (2001) The interactive effect of cadmium chloride and ultraviole radiation in the albino rat: histopathological, histochemical and physiological studies. Ph.D. Thesis. Faculty of science. Cairo University.

58. El-Banhawy M, El-Tounsy M, Farid N and El-Salkh B (1990) Histochemical studies on the effect of Curacron on the adrenal gland of rat. Egypt J Histo 13 207-217.

59. El- Asar AA, Eid FA and El-Sayed FM (1988) Radioprotective effect of WR 2721 on hepatic cells (an ultrastructural study). Egypt J Histo 11: 141-146.

60. Khadiga IMM, Shadia MM (1995) Structural changes in rat induced by dietary addition of monosodium glutamate. Egypt $\mathrm{J}$ Histol 2: 423-430

61. Sakano K, Kawanishi S (2002) Metal-mediated DNA damage induced by curcumin in the presence of human cytochrome P450 isozymes. Arch Biochem Biophys 405: 223-230.

62. Sahu SC, Washington MC (1992) Effect of ascorbic acid and curcumin on quercetin-induced nuclear DNA damage, lipid peroxidation and protein degradation. Cancer Lett 63: 237-241. 